\title{
30. DATA REPORT: OXIDES, SULFIDES, AND ASSOCIATED PHASES IN VEINS AND HYDROTHERMALLY ALTERED PERIDOTITIC ROCKS ${ }^{1}$
}

\author{
Laura Gaggero, ${ }^{2}$ Luciano Cortesogno, ${ }^{2}$ and Moreno Gazzotti ${ }^{3}$
}

\begin{abstract}
The ductile to brittle deformation and the associated hydrothermal mineralogical record in Holes 920B and 920D peridotites are complex. Remnants of a high-temperature phase (brown hornblende, talc) are preserved in the serpentinized harzburgites. Primary chromites in the harzburgite are altered to ferritchromite. Magnetite, which originated from olivine breakdown during serpentinization, (1) recrystallizes, mimicking mesh and ribbon textures, and (2) reorganizes in veins and trails. Primary sulfide minerals rarely survive the extensive serpentinization, and are affected by significant mobilization.

An ilvaite + chlorite + fibrous salitic pyroxene \pm carbonate \pm grandite garnet + magnetite \pm sulfides (pyrite $>$ pyrrhotite $>$ chalcopyrite) assemblage that developed in pyroxenite veins is cut by later serpentine veins. Late hydrothermal veins, pyrite (+ silicates) precipitate in veins, which are cut in turn by pyrrhotite + chalcopyrite (+ phyllosilicate) veins.
\end{abstract}

\section{PETROGRAPHIC FEATURES}

Petrographic features and intersection criteria allow us to discriminate three main events in Holes 920B and 920D harzburgites: (1) hydrous alteration preceding serpentinization, (2) the main serpentinization, and (3) late processes that overprint the serpentinite texture. A polyphase set of composite macroscopic veins is developed through the peridotite and is less developed in gabbro and diabase intervals. Pyroxenitic and gabbroic veins of magmatic origin are discordant with the high-temperature plastic fabric, and predate the development of serpentine-bearing veins (Shipboard Scientific Party, 1995, fig. 22).

Vein systems are the most characteristic features associated with fluid introduction during serpentinization, and control metamorphic recrystallization during uplift. Different sets of hydrothermal veins, ascribed to the main serpentinization and to late processes overprinting the serpentinite texture, were distinguished in chronological order on the basis of visual core descriptions (Shipboard Scientific Party, 1995):

1. Serpentine + magnetite veins. An early net of fine serpentine veins $(0.03-0.05 \mathrm{~mm}$ wide) postdates the intrusion of igneous veins. The serpentine veining is associated with the pervasive background alteration of olivine and orthopyroxene.

2. Serpentine + amphibole \pm chlorite \pm talc. This set of veins is poorly developed, and consists of dark-green to black veins, 2-3 mm wide. An alteration halo of chlorite \pm serpentine \pm amphibole is commonly present along the vein-host rock boundary.

3. Serpentine + magnetite. These veins (up to $1 \mathrm{~mm}$ wide) occur as a widespread anastomosing network of white serpentine and black magnetite around orthopyroxene porphyroclasts.

4. Serpentine \pm carbonate \pm pyrite \pm clay minerals. Wide (about $5 \mathrm{~mm}$ ), randomly oriented, open fractures are filled by radiat-

'Karson, J.A., Cannat, M., Miller, D.J., and Elthon, D., (Eds.), 1997. Proc. ODP, Sci. Results, 153: College Station, TX (Ocean Drilling Program).

Dipartimento di Scienze della Terra, Università di Genova, Corso Europa 26, I16132 Genova, Italy. gaggero@dister.unige.it

'Dipartimento di Scienze della Terra, Università di Modena, Piazzale S. Eufemia 36, I-41100 Modena, Italy. ing chrysotile and aragonite and are coated by sulfides and minor phyllosilicates.

5. Carbonate minerals \pm sulfides \pm smectite. This set is represented by a thin (up to $1 \mathrm{~mm}$ wide) network with a random orientation that has sometimes reactivated earlier vein arrays. The serpentinization of harzburgite is widespread and, in part, obscures earlier alteration phases (Shipboard Scientific Party, 1995).

In the present study, minerals were identified and phase relationships determined by optical examination of 36 polished thin sections in transmitted and reflected light. Quantitative electron microprobe analyses of mineral phases were determined using a scanning electron microscope (SEM-EDS) equipped with an X-ray dispersive analyzer (EDAX PV 9100) microprobe, installed at the Dipartimento di Scienze della Terra, Università di Genova. Operating conditions were $15-\mathrm{kV}$ accelerating voltage and $2.20-\mathrm{nA}$ beam current. Natural standards were used.

The cation sum of $\mathrm{Ca}$ amphiboles was normalized to $13-(\mathrm{Ca}+$ $\mathrm{Na}+\mathrm{K}$ ), as suggested by Laird and Albee (1981); $\mathrm{Fe}^{3+}=46-$ total cation charge, and $\mathrm{Fe}^{2+}=\mathrm{Fe}_{\text {tot }}-\mathrm{Fe}^{3+} ; \mathrm{Al}^{\mathrm{VI}}=8-\mathrm{Si}$, and $\mathrm{Al}^{\mathrm{IV}}=\mathrm{Al}_{\text {tot }}-$ $\mathrm{Al}^{\mathrm{VI}}$. The nomenclature of Leake (1978) was adopted. $\mathrm{H}_{2} \mathrm{O}$ was allocated on the basis of stoichiometric $\mathrm{OH}^{-}$. Plagioclase analyses were recalculated to total cations $=5$, on the basis of 8 oxygens. Garnets were recalculated to total cations $=8$, on the basis of 12 oxygens; end members were recast according to Rickwood (1968). Chromites were recast on the basis of 4 oxygens. Ilvaite was recast to 6 cations and 8.5 oxygens.

\section{Silicates}

Little textural evidence of recrystallization triggered by seawaterderived fluids survived the extensive serpentinization; relicts are represented by calcic amphiboles, mostly brown hornblende (Table 1), developed on pyroxenes rimming or sealing microfractures, more rarely rimming spinels or filling veinlets. Brown hornblendes are tschermakites, with $\mathrm{TiO}_{2}$ up to $3.95 \mathrm{wt} \%$ (Fig. 1). In most cases, brown hornblende shows polyphasic rims of green hornblende (tschermakitic hornblende, $\mathrm{Mg}$-hornblende) and rarer actinolite (Fig. 1).

The serpentine developed as mesh or, rarely, in ribbon textures; chlorite developed on plagioclase (in gabbroic veins) and spinels (in serpentinized harzburgite). 
Table 1. Mineral compositions of amphiboles from Holes 920B and 920D.

\begin{tabular}{|c|c|c|c|c|c|c|c|c|c|c|c|}
\hline Hole: & $920 \mathrm{~B}$ & $920 \mathrm{~B}$ & $920 \mathrm{~B}$ & $920 \mathrm{~B}$ & $920 \mathrm{~B}$ & $920 \mathrm{~B}$ & $920 \mathrm{~B}$ & $920 \mathrm{~B}$ & $920 \mathrm{~B}$ & 920D & 920D \\
\hline Core, section: & 13R-2 & 13R-2 & 13R-2 & 13R-2 & $13 R-2$ & $13 \mathrm{R}-2$ & 13R-2 & $13 R-2$ & $13 R-2$ & $2 \mathrm{R}-1$ & 2R-1 \\
\hline Interval $(\mathrm{cm})$ : & $122-127$ & $122-127$ & $122-127$ & $122-127$ & $122-127$ & $122-127$ & $122-127$ & $122-127$ & $122-127$ & $138-140$ & $138-140$ \\
\hline Analysis no.: & 1 & 2 & 3 & 4 & 5 & 6 & 7 & 8 & 9 & 1 & 2 \\
\hline $\begin{array}{l}\text { Oxides } \\
\mathrm{SiO}_{2} \\
\mathrm{TiO}_{2} \\
\mathrm{Cr}_{2} \mathrm{O}_{3} \\
\mathrm{Al}_{2} \mathrm{O}_{3} \\
\mathrm{Fe}_{2} \mathrm{O}_{3} \\
\mathrm{FeO}_{\mathrm{O}} \mathrm{MnO} \\
\mathrm{MgO} \\
\mathrm{CaO} \\
\mathrm{Na} \mathrm{O}_{2} \mathrm{O} \\
\mathrm{K}_{2} \mathrm{O} \\
\mathrm{H}_{2} \mathrm{O} \\
\text { Total }\end{array}$ & $\begin{array}{r}43.41 \\
3.64 \\
0.13 \\
10.62 \\
5.02 \\
11.86 \\
0.31 \\
10.19 \\
10.66 \\
1.78 \\
0.21 \\
2.03 \\
99.86\end{array}$ & $\begin{array}{r}43.40 \\
3.95 \\
0.10 \\
10.40 \\
4.34 \\
12.40 \\
0.30 \\
10.31 \\
10.60 \\
2.07 \\
0.20 \\
2.03 \\
100.09\end{array}$ & $\begin{array}{r}44.36 \\
3.58 \\
0.12 \\
10.10 \\
4.75 \\
12.61 \\
0.23 \\
10.41 \\
10.80 \\
1.83 \\
0.29 \\
2.05 \\
101.13\end{array}$ & $\begin{array}{r}43.24 \\
2.43 \\
0.19 \\
11.23 \\
6.67 \\
9.20 \\
0.21 \\
11.80 \\
11.21 \\
1.97 \\
0.34 \\
2.05 \\
100.54\end{array}$ & $\begin{array}{r}43.18 \\
2.61 \\
0.11 \\
11.16 \\
6.78 \\
9.37 \\
0.25 \\
11.67 \\
11.21 \\
1.91 \\
0.36 \\
2.05 \\
100.66\end{array}$ & $\begin{array}{r}44.21 \\
3.62 \\
0.17 \\
9.89 \\
3.87 \\
12.52 \\
0.27 \\
10.78 \\
10.90 \\
1.74 \\
0.55 \\
2.04 \\
100.56\end{array}$ & $\begin{array}{r}43.54 \\
2.47 \\
0.17 \\
11.55 \\
7.67 \\
5.89 \\
0.17 \\
13.67 \\
11.27 \\
2.15 \\
0.30 \\
2.08 \\
100.93\end{array}$ & $\begin{array}{r}42.96 \\
3.57 \\
0.18 \\
11.42 \\
7.02 \\
8.45 \\
0.20 \\
11.93 \\
10.84 \\
2.03 \\
0.33 \\
2.07 \\
100.99\end{array}$ & $\begin{array}{r}43.13 \\
3.65 \\
0.22 \\
11.34 \\
7.16 \\
8.00 \\
0.26 \\
12.29 \\
10.94 \\
2.03 \\
0.36 \\
2.08 \\
101.46\end{array}$ & $\begin{array}{r}46.55 \\
1.24 \\
0.62 \\
10.63 \\
5.25 \\
0.00 \\
0.17 \\
18.97 \\
11.66 \\
2.39 \\
0.21 \\
2.14 \\
99.83\end{array}$ & $\begin{array}{r}45.80 \\
1.50 \\
1.16 \\
11.93 \\
3.72 \\
0.00 \\
0.09 \\
19.31 \\
11.78 \\
2.56 \\
0.27 \\
2.16 \\
100.28\end{array}$ \\
\hline $\begin{array}{l}\mathrm{Si} \\
\mathrm{Ti} \\
\mathrm{Cr} \\
\mathrm{Al} \\
\mathrm{Fe}^{3+} \\
\mathrm{Fe}^{2+} \\
\mathrm{Mn} \\
\mathrm{Mg} \\
\mathrm{Ca} \\
\mathrm{Na} \\
\mathrm{K} \\
\mathrm{OH}\end{array}$ & $\begin{array}{l}6.419 \\
0.405 \\
0.015 \\
1.851 \\
0.559 \\
1.467 \\
0.039 \\
2.246 \\
1.689 \\
0.510 \\
0.040 \\
2.000\end{array}$ & $\begin{array}{l}6.414 \\
0.439 \\
0.012 \\
1.812 \\
0.482 \\
1.533 \\
0.038 \\
2.271 \\
1.679 \\
0.593 \\
0.038 \\
2.000\end{array}$ & $\begin{array}{l}6.488 \\
0.394 \\
0.014 \\
1.741 \\
0.523 \\
1.542 \\
0.029 \\
2.270 \\
1.693 \\
0.519 \\
0.054 \\
2.000\end{array}$ & $\begin{array}{l}6.321 \\
0.267 \\
0.022 \\
1.935 \\
0.734 \\
1.124 \\
0.026 \\
2.571 \\
1.756 \\
0.558 \\
0.063 \\
2.000\end{array}$ & $\begin{array}{l}6.312 \\
0.287 \\
0.013 \\
1.923 \\
0.746 \\
1.146 \\
0.031 \\
2.543 \\
1.756 \\
0.541 \\
0.067 \\
2.000\end{array}$ & $\begin{array}{l}6.502 \\
0.400 \\
0.020 \\
1.714 \\
0.428 \\
1.539 \\
0.034 \\
2.363 \\
1.717 \\
0.496 \\
0.103 \\
2.000\end{array}$ & $\begin{array}{l}6.264 \\
0.267 \\
0.019 \\
1.958 \\
0.830 \\
0.708 \\
0.021 \\
2.931 \\
1.737 \\
0.600 \\
0.055 \\
2.000\end{array}$ & $\begin{array}{l}6.237 \\
0.390 \\
0.021 \\
1.954 \\
0.767 \\
1.026 \\
0.025 \\
2.582 \\
1.686 \\
0.571 \\
0.061 \\
2.000\end{array}$ & $\begin{array}{l}6.227 \\
0.396 \\
0.025 \\
1.930 \\
0.779 \\
0.966 \\
0.032 \\
2.645 \\
1.692 \\
0.568 \\
0.066 \\
2.000\end{array}$ & $\begin{array}{l}6.516 \\
0.131 \\
0.069 \\
1.754 \\
0.553 \\
0.000 \\
0.020 \\
3.958 \\
1.749 \\
0.649 \\
0.038 \\
2.000\end{array}$ & $\begin{array}{l}6.364 \\
0.157 \\
0.127 \\
1.954 \\
0.389 \\
0.000 \\
0.011 \\
3.999 \\
1.754 \\
0.690 \\
0.048 \\
2.000\end{array}$ \\
\hline
\end{tabular}

Notes: Values are in weight percent. Cations were calculated on the basis of 23 oxygens and 13 cations $+\mathrm{K}+\mathrm{Na}+\mathrm{Ca}$.

\section{Oxides}

In addition to serpentine, opaque phases are the most abundant neoblastic minerals resulting from olivine alteration. Magnetite is a widespread alteration phase, and it develops as (1) trails of irregularly shaped grains in the mesh textures, (2) disseminated grains, or (3) aggregates of grains parallel to ribbon textures.

Magnetite contains sulfide microinclusions and intergrowths in recrystallized aggregates. The most abundant sulfide is pyrite, but lesser pyrrhotite and chalcopyrite can also be present. In samples affected by more pervasive recrystallization, magnetite coexisting with serpentine and chlorite develops in large subhedral or atoll grains (about $100 \mu \mathrm{m}$ in size).

Coarser grained magnetite (about $100 \mu \mathrm{m}$ ) originates from the alteration of the chromian spinel. The alteration of chromite (Table 2) in harzburgite and gabbroic veins and its progressive replacement from grain margins to interiors by ferritchromite and/or magnetite are illustrated in Figure 2, and are reflected in mineral chemistry. Compositions of primary and secondary spinels are reported in Figure 3.

In Sample 153-920D-18R-3, 50-54 cm, a pyroxenite vein, vermicular textures of ilmenite, magnetite, and orthopyroxene (Fig. 4) developed during high-temperature subsolidus recrystallization, as indicated by phase stability and by textural relationships between lower-temperature assemblages.

\section{Sulfides}

In later vein sets, the sulfide grain size increases; inclusions or intergrowths of pyrite, chalcopyrite, and pyrrhotite within magnetite become common. Sulfides are also relatively common phases in serpentinized harzburgites. Primary sulfides are represented by subhedral grains of pentlandite (Sample 153-920D-4R-1, 60-65 cm) and minor chalcopyrite and pyrrhotite. Pentlandite is largely altered to violarite, and sometimes shows flame exsolutions of mackinawite. In magmatic pyroxenite and gabbroic veins, pentlandite associated with pyrrhotite and chalcopyrite occurs with ilmenite as an interstitial phase. In some cases, the iron-bearing mineral present in the meshtextured serpentinite is pyrite and/or bravoite, rarely with chalcopy- rite in very fine-grained cloudy disseminations. The sulfide micrograins are commonly rimmed by magnetite. Vein-filling sulfides are mainly pyrrhotite, pyrite, chalcopyrite, and trace sphalerite, sometimes associated with phyllosilicate or saponite-type minerals. Sulfides in veins occur as large (up to $1 \mathrm{~mm}$ ), generally monophase aggregates, or as euhedral singular grains. Pyrrhotite is commonly intergrown with a phyllosilicate mineral (e.g., Sample 153-920-8R-1, $6-11 \mathrm{~cm}$ ) and invades the host serpentinite (Fig. 5). Relationships with serpentine textures show that pyrrhotite development occurs after serpentinization. Pyrrhotite also occurs as large tabular grains intergrown with chlorite lamellae, sometimes including chalcopyrite or sphalerite. Pyrrhotite is partially replaced by pyrite in small veins. The sulfide developed during the main serpentinization event is pyrite, whereas chalcopyrite is prevalent in late veins that cut the mesh textures.

\section{Secondary Silicates in Veins}

During serpentinization, resulting either from the presence of $\mathrm{Ca}$ rich primary phases (in magmatic veins, see plagioclase composition in Fig. 1) and/or from fluid-related recrystallization, secondary $\mathrm{Ca}$ silicates develop in fractures and veins. These assemblages are characterized by Ca pyroxene (diopside to salite), actinolite, with talc and chlorite (Samples 153-920D-8R-1, 6-11 cm; 6R-2, 27-30 cm; 21R$3,36-42 \mathrm{~cm} ; 20 \mathrm{R}-2,64-67 \mathrm{~cm})$. More rarely, vesuvianite, calcic garnet (andradite or grossular, Sample 153-920D-22R-7, 121-124 cm; Fig. 1; Table 3), and $\mathrm{Ca}$ carbonate are present. Epidote occurrence is restricted to late cataclastic zones across gabbroic veins. The occurrence of ilvaite (Table 4) in the core from Hole 920D is noteworthy. It is present in magmatic (clinopyroxene + orthopyroxene + plagioclase) pyroxenite veins ( $1 \mathrm{~cm}$ thick), and also in metamorphic veins with calcic phases. The stable association is ilvaite + chlorite + fibrous salitic pyroxene \pm carbonate \pm grandite garnet + magnetite. Ilvaite patches are often cut by secondary fibrous serpentine veins, indicating that ilvaite formed during an early stage of the serpentinization process. Sulfide patches (pyrrhotite, chalcopyrite, pyrite) are locally associated with ilvaite (Fig. 6). Ilvaite is a common phase in Ca-Fe-Si skarns, stable at relatively high $f \mathrm{H}_{2} \mathrm{O}$, low $f \mathrm{CO}_{2}$, low $f \mathrm{O}_{2}$, 
A

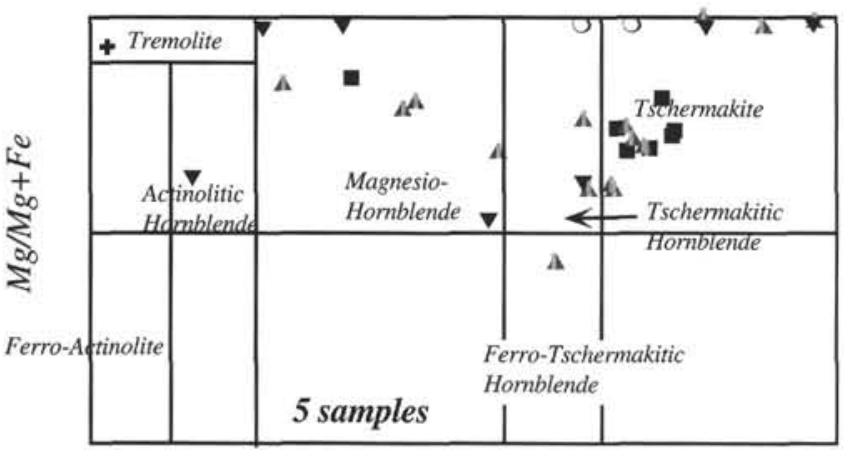

Si a.p.f.u.

B

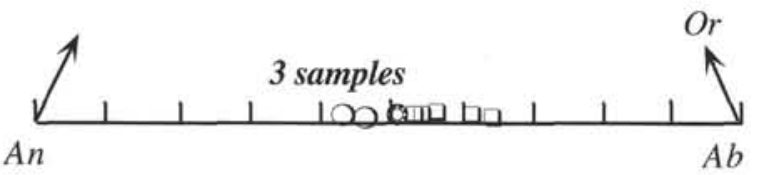

C

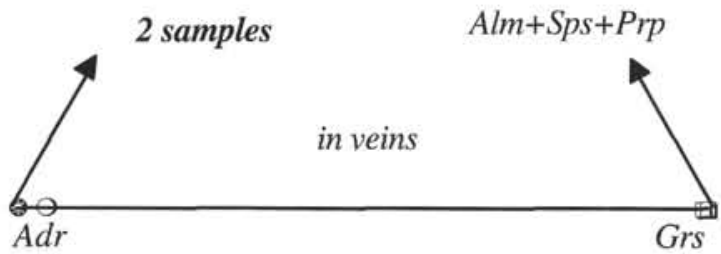

Figure 1. Mineral chemistry of secondary silicates (A) brown amphiboles to actinolites (Leake, 1978); (B) composition of plagioclase in magmatic veins in the anorthite-albite-orthoclase (An-Ab-Or) diagram; and (C) garnets overgrowing plagioclase in gabbroic veins in the ternary diagram for andradite (Adr), grossular (Grs), and almandine + spessartine + pyrope (Alm + Sps + Prp). Different symbols represent analyses from different samples; a.p.f.u. = atoms per formula unit.

and moderate to low temperatures (Burt, 1971). Ilvaite is also described as an alteration product of olivine in the Skaergaard intrusion, as a result of the metasomatic introduction of $\mathrm{CaO}$ and fluids in the system (Naslund et al., 1983). In the Ca-Fe-Si-OH system, ilvaite is stable up to $470 \pm 25^{\circ} \mathrm{C}$ for $\mathrm{P}\left(\mathrm{H}_{2} \mathrm{O}\right)=0.2 \mathrm{GPa}$, and $f \mathrm{O}_{2}$ between the NNO and FMQ buffers (Gustafson, 1974). At higher oxygen fugacity, ilvaite alters to quart $z+$ magnetite + andradite $+\mathrm{H}_{2} \mathrm{O}$, or to hedenbergite + magnetite $+\mathrm{H}_{2} \mathrm{O}$.
In samples from Hole 920D, serpentine veins cutting ilvaite patches suggest that ilvaite formed during the early phases of serpentinization of the ultramafic rocks, in the presence of $\mathrm{Ca}$-enriched hydrous fluids with low $f \mathrm{O}_{2}$ and $f \mathrm{CO}_{2}$. Hole 920D ilvaite differs from most common occurrences because of the presence of high $\mathrm{Mg}$ and $\mathrm{Al}$ in the system. In similar paragenetic assemblages, ilvaite occurs in metarodingites reequilibrated at temperatures between $450^{\circ}$ and $500^{\circ} \mathrm{C}$ and high pressure (Lucchetti, 1989).

In late hydrothermal veins, concentrations of magnetite, serpentine, and talc are locally associated with patchy lamellar aggregates of phyllosilicates (tobermorite-group minerals and saponites not yet analyzed).

Following serpentinization, chalcopyrite and pyrrhotite precipitation precedes pyrite in veins and fractures filled by saponite-type phyllosilicates and minor oxides. The timing of sulfide deposition is likely related to the increasing water/rock interaction, and is consistent with decreasing temperatures (Kissin and Scott, 1982).

\section{ACKNOWLEDGMENTS}

This work was performed with the CNR-Italy contribution A.I. 94.00868. The authors thank L. Negretti for help in mineral data acquisition.

\section{REFERENCES}

Burt, D.M., 1971. Multisystem analysis of the relative stabilities of babingtonite and ilvaite. Ann. Rep. Dir., Geophys. Lab., Year Book-Carnegie Inst. Washington, 70:189-197.

Gustafson, W.I., 1974. The stability of andradite, hedenbergite, and related minerals in the system Ca-Fe-Si-O-H. J. Petrol., 15:455-496.

Kissin, S.A., and Scott, S.D., 1982. Phase relations involving pyrrhotite below $350^{\circ}$ C. Econ. Geol., 77:1739-1754.

Laird, J., and Albee, A.L., 1981. Pressure, temperature, and time indicators in mafic schist: their application to reconstructing the polymetamorphic history of Vermont. Am. J. Sci., 281:97-126.

Leake, B.E., 1978. Nomenclature of amphiboles. Can. Mineral., 16:501520.

Lucchetti, G., 1989. High pressure ilvaite bearing assemblages from the Voltri Group (Italy). Neues. Jahrb. Mineral. Monatsh., 1:1-7.

Naslund, H.R., Hughes, J.M., and Birnie, R.W., 1983. Ilvaite, an alteration product replacing olivine in the Skaergaard intrusion. Am. Mineral., 68:1004-1008.

Rickwood, P.C., 1968. On recasting analyses of garnet into end-members molecules. Contrib. Mineral. Petrol., 18:175-198.

Shipboard Scientific Party, 1995. Site 920. In Cannat, M., Karson, J.A., Miller, D.J., et al., Proc. ODP, Init. Repts., 153: College Station, TX (Ocean Drilling Program), 45-119.

Date of initial receipt: 3 August 1995

Date of acceptance: 22 March 1996

Ms 153SR-034 
Table 2. Selected mineral compositions of oxide minerals from Holes 920B and 920D.

\begin{tabular}{|c|c|c|c|c|c|c|c|c|c|c|c|c|c|c|c|c|c|c|c|c|}
\hline Hole: & $920 \mathrm{~B}$ & $920 \mathrm{~B}$ & $920 \mathrm{~B}$ & $920 \mathrm{D}$ & $920 \mathrm{D}$ & 920D & $920 \mathrm{D}$ & 920D & 920D & $920 \mathrm{D}$ & $920 \mathrm{D}$ & $920 \mathrm{D}$ & $920 \mathrm{D}$ & $920 \mathrm{D}$ & $920 \mathrm{D}$ & $920 \mathrm{D}$ & $920 \mathrm{D}$ & $920 \mathrm{D}$ & $920 \mathrm{D}$ & 920D \\
\hline Core, section: & IW-3 & $5 \mathrm{R}-1$ & $5 \mathrm{R}-1$ & $10 \mathrm{R}-4$ & $10 \mathrm{R}-4$ & $15 \mathrm{R}-5$ & $19 \mathrm{R}-2$ & $19 \mathrm{R}-2$ & 20R-2 & $20 \mathrm{R}-2$ & $4 \mathrm{R}-1$ & $4 \mathrm{R}-1$ & $4 \mathrm{R}-1$ & $4 \mathrm{R}-1$ & $6 \mathrm{R}-2$ & $6 \mathrm{R}-2$ & $6 R-3$ & $8 \mathrm{R}-1$ & $8 \mathrm{R}-1$ & $9 \mathrm{R}-2$ \\
\hline Interval (cin): & $108-116$ & 73-77 & 73-77 & $14-21$ & $14-21$ & $43-50$ & $123-128$ & $123-128$ & $8 \quad 64-67$ & 64-67 & $60-65$ & $60-65$ & $60-65$ & $60-65$ & $27-30$ & $27-30$ & $88-92$ & $6-11$ & $6-11$ & $25-31$ \\
\hline Analysis no.: & 1 & 1 & 2 & 1 & 2 & 1 & 1 & 2 & 1 & 2 & 1 & 2 & 3 & 4 & 1 & 2 & 1 & 1 & 2 & 1 \\
\hline Mineral: & Spinel & Spinel & Spinel & Spinel & Spinel & Spinel & Spinel & Spinel & Chromite & Spinel & Spinel & Spinel & Spinel & Spinel & Chromite & Chromite & Spinel & Spinel & Spinel & Spinel \\
\hline \multicolumn{21}{|l|}{ Oxides } \\
\hline & 0.12 & 0.11 & 2.84 & 0.03 & 4.32 & 0.02 & 0.03 & 9.70 & 0.11 & 0.10 & 0.06 & 10.13 & 0.63 & 6.38 & 0.02 & 0.08 & 0.22 & 0.15 & 0.02 & 0.20 \\
\hline $\mathrm{Tic}$ & & 0.24 & 0.19 & 0.09 & 0.15 & 1.25 & 0.14 & 0.18 & 0.19 & 0.11 & 0.14 & 0.14 & 0.12 & 0.18 & 0.17 & 0.19 & 0.12 & 0.63 & 0.19 & 9.24 \\
\hline $\begin{array}{l}\mathrm{Cr}_{2} \mathrm{O}_{3} \\
\mathrm{Al}_{2} \mathrm{O}_{3}\end{array}$ & $\begin{array}{l}25.46 \\
40.45\end{array}$ & $\begin{array}{l}29.04 \\
40.64\end{array}$ & $\begin{array}{r}23.44 \\
0.36\end{array}$ & $\begin{array}{l}25.03 \\
43.94\end{array}$ & $\begin{array}{r}15.90 \\
5.19\end{array}$ & $\begin{array}{r}19.32 \\
0.12\end{array}$ & $\begin{array}{l}25.61 \\
43.85\end{array}$ & $\begin{array}{r}27.03 \\
1.32\end{array}$ & $\begin{array}{l}29.03 \\
39.86\end{array}$ & $\begin{array}{l}39.20 \\
25.21\end{array}$ & $\begin{array}{r}27.29 \\
42.33\end{array}$ & $\begin{array}{r}25.28 \\
1.85\end{array}$ & $\begin{array}{r}23.92 \\
0.00\end{array}$ & $\begin{array}{c}22.19 \\
0.654\end{array}$ & $\begin{array}{r}26.56 \\
3.04\end{array}$ & $\begin{array}{l}25.97 \\
42.55\end{array}$ & $\begin{array}{l}23.81 \\
45.70\end{array}$ & $\begin{array}{l}41.26 \\
24.19\end{array}$ & $\begin{array}{l}28.05 \\
40.09\end{array}$ & $\begin{array}{r}24.39 \\
4.86\end{array}$ \\
\hline $\begin{array}{l}\mathrm{Al}_{2} \mathrm{O}_{3} \\
\mathrm{Fe} \mathrm{O}_{3}\end{array}$ & $\begin{array}{r}40.45 \\
3.25\end{array}$ & $\begin{array}{r}40.64 \\
1.69\end{array}$ & $\begin{array}{r}0.36 \\
39.38\end{array}$ & $\begin{array}{r}43.94 \\
1.44\end{array}$ & $\begin{array}{r}5.19 \\
38.68\end{array}$ & $\begin{array}{r}0.12 \\
47.25\end{array}$ & $\begin{array}{r}43.85 \\
1.53\end{array}$ & $\begin{array}{r}1.32 \\
21.87\end{array}$ & $\begin{array}{r}39.86 \\
1.28\end{array}$ & $\begin{array}{r}25.21 \\
4.16\end{array}$ & $\begin{array}{r}42.33 \\
1.71\end{array}$ & $\begin{array}{r}1.85 \\
23.71\end{array}$ & $\begin{array}{r}0.00 \\
42.55\end{array}$ & $\begin{array}{l}0.654 \\
33.37\end{array}$ & $\begin{array}{l}3.04 \\
1.36\end{array}$ & $\begin{array}{r}42.55 \\
1.14\end{array}$ & $\begin{array}{r}45.70 \\
0.84\end{array}$ & $\begin{array}{r}24.19 \\
1.54\end{array}$ & $\begin{array}{r}40.09 \\
1.45\end{array}$ & $\begin{array}{r}4.86 \\
20.25\end{array}$ \\
\hline $\begin{array}{l}\mathrm{Fe}_{2} \mathrm{O}_{3} \\
\mathrm{FeO}\end{array}$ & $\begin{array}{r}3.25 \\
17.91\end{array}$ & $\begin{array}{r}1.69 \\
12.60\end{array}$ & $\begin{array}{l}39.38 \\
27.78\end{array}$ & $\begin{array}{l}1.44 \\
13.66\end{array}$ & $\begin{array}{l}38.68 \\
24.10\end{array}$ & $\begin{array}{l}47.25 \\
30.85\end{array}$ & $\begin{array}{r}1.53 \\
12.84\end{array}$ & $\begin{array}{l}21.87 \\
25.14\end{array}$ & $\begin{array}{r}1.28 \\
14.32\end{array}$ & $\begin{array}{r}4.16 \\
19.84\end{array}$ & $\begin{array}{l}1.71 \\
12.57\end{array}$ & $\begin{array}{l}23.71 \\
21.97\end{array}$ & $\begin{array}{l}42.55 \\
24.47\end{array}$ & $\begin{array}{l}33.37 \\
25.14\end{array}$ & $\begin{array}{r}1.36 \\
11.60\end{array}$ & $\begin{array}{r}1.14 \\
11.87\end{array}$ & $\begin{array}{r}0.84 \\
12.85\end{array}$ & $\begin{array}{r}1.54 \\
24.21\end{array}$ & $\begin{array}{r}1.45 \\
12.47\end{array}$ & $\begin{array}{l}20.25 \\
37.61\end{array}$ \\
\hline $\mathrm{MnO}$ & 0.36 & 0.08 & 4.36 & 0.00 & 5.20 & 1.78 & 0.18 & 4.87 & 0.06 & 0.11 & 0.08 & 5.85 & $\begin{array}{l}24.41 \\
7.35\end{array}$ & 4.85 & 0.00 & 0.11 & 0.07 & 0.00 & 0.10 & 1.81 \\
\hline M & 13.62 & 17.43 & 2.13 & 16.81 & 5.33 & 0.00 & 17.32 & 9.33 & 16.00 & 10.41 & 17.49 & 11.34 & 0.01 & 6.28 & 18.05 & 17.53 & 17.69 & & 16.72 & 0.88 \\
\hline $\mathrm{C}$ & 0.06 & 0.06 & 0.15 & 0.04 & 0.24 & 0.09 & 0.10 & 0.29 & & 0.08 & 0.05 & 0.23 & 0.19 & 0.23 & 0.06 & 0.06 & 0.10 & & & 0.12 \\
\hline Total & 101.43 & 101.89 & 100.63 & 101.04 & 99.12 & 100.68 & 101.59 & 99.73 & 100.92 & 99.22 & 101.72 & 100.50 & 99.23 & 99.27 & 100.86 & 99.50 & 101.39 & 100.17 & 99.24 & 99.36 \\
\hline \multicolumn{21}{|l|}{ Cations } \\
\hline & & 0. & 0. & 0.001 & 0.153 & 0.001 & & 0.3 & 0.0 & 0.003 & 0.002 & 0.335 & 0.024 & 0.226 & 0.001 & 0.0 & 0.006 & 0.005 & 0.001 & 0.007 \\
\hline $\mathrm{T}$ & & & & 0.002 & 0.004 & 0.036 & 3 & 5 & 0.0 & 0.003 & 0.003 & 0.004 & 0.003 & 0.005 & 0.004 & 0.0 & 0.002 & 0.015 & 0.004 & 0.255 \\
\hline C & & & & 0.5 & 0.4 & 0.578 & & 0. & & 0.9 & 0.5 & 0. & 0.722 & 0.622 & 0.5 & & & 1.027 & 0.626 & 0.707 \\
\hline A & & 1.3 & & 1.422 & 0.216 & 0.005 & & & 1.3 & 0.926 & 1.365 & 0.072 & 0.000 & 0.027 & 1.389 & 1.393 & 1.457 & 0.897 & 1.334 & 0.210 \\
\hline $\mathrm{Fc}$ & & & & 0.030 & 1.027 & 1.345 & & & & 0.098 & 0.0 & 0.590 & 1.223 & 0.890 & 0.028 & 0.024 & 0.017 & 0.037 & 0.031 & 0.559 \\
\hline $\mathrm{Fe}^{2+}$ & & & & & 0.712 & 0.976 & & & & & & & 0.781 & 0.745 & & & & & 0.294 & 1.153 \\
\hline $\mathrm{Mn}$ & & & & & & 0 . & & & & & & & 0.2 & 0.146 & 0. & & & & 0.002 & 0.056 \\
\hline $\mathrm{Mg}$ & & & & & & & & & & & & & 0.0 & 2 & 0.7 & & & & 0.704 & 0.048 \\
\hline $\mathrm{Ca}$ & 0.002 & 0.002 & 0.006 & 0.001 & 0.009 & 0.004 & 0.003 & 0.011 & 0.002 & 0.003 & 0.002 & 0.008 & 0.008 & 0.009 & 0.002 & 0.002 & 0.003 & 0.005 & 0.004 & 0.005 \\
\hline \multicolumn{21}{|l|}{ End members } \\
\hline tid & 0 & 0.005 & 0 & 0.00 & 0.353 & 0. & 0. & 0.191 & 0.0 & 0.0 & 0.0 & 0.1 & 0.3 & 0.317 & 0.0 & 0.0 & 0.002 & 0.011 & 0.004 & 0.231 \\
\hline & & & & & & & & & & & & & & & & & & & & \\
\hline & & & & & & & & & & & & & & & & & & & & 0.033 \\
\hline & & & & & & & & & & & & & & & & & & & & 0.006 \\
\hline & & & & & & & 0 & & & 0.2 & 0. & 0.0 & 0.0 & 0.0 & 0. & 0. & 0. & 0.278 & 0.192 & 0.087 \\
\hline & & & & 0.00 & 0.024 & & 0. & 0.0 & 0.0 & 0.0 & 0.0 & 0.0 & 0.000 & 0.004 & 0.0 & 0.1 & 0. & 0. & 0.002 & 0.012 \\
\hline Chrs & 0. & 0.0 & 0.3 & 0.08 & 0.187 & 0.289 & 0.0 & 0.323 & 0.1 & 0.2 & 0.0 & 0.2 & 0.370 & 0.277 & 0.0 & 0.0 & 0. & 0. & 0.091 & 0.331 \\
\hline $\mathrm{Mg}$ c & 0. & 0.2 & 0.0 & 0.18 & 0.075 & 0.000 & 0.19 & 0.216 & 0.2 & 0.2 & 0.212 & 0.240 & 0.000 & 0.125 & 0.213 & 0.209 & 0.183 & 0.198 & 0.223 & 0.025 \\
\hline Ulvöspinel & 0.004 & 0.005 & 0.005 & 0.002 & 0.004 & 0.036 & 0.003 & 0.005 & 0.004 & 0.003 & 0.003 & 0.003 & 0.003 & 0.005 & 0.004 & 0.004 & 0.002 & 0.015 & 0.004 & 0.255 \\
\hline
\end{tabular}

Notes: Values are in weight percent. Cations were calculated assuming stoichiometry and charge balance. 


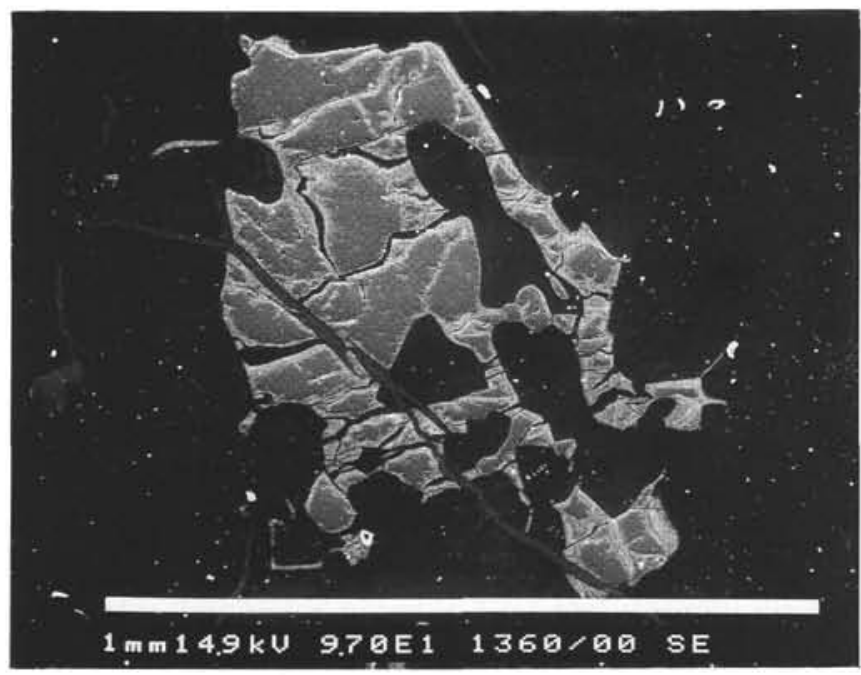

Figure 2. Secondary electron photomicrograph, Sample 153-920D-6R-1, 27$30 \mathrm{~cm}$. Bar scale in photograph is $1 \mathrm{~mm}$. A corroded primary spinel (gray) has altered (light gray-white) to ferritchromite and magnetite, which are diffusing from microcracks. A large chlorite vein (dark gray) cuts from the top left to the bottom right of the grain.
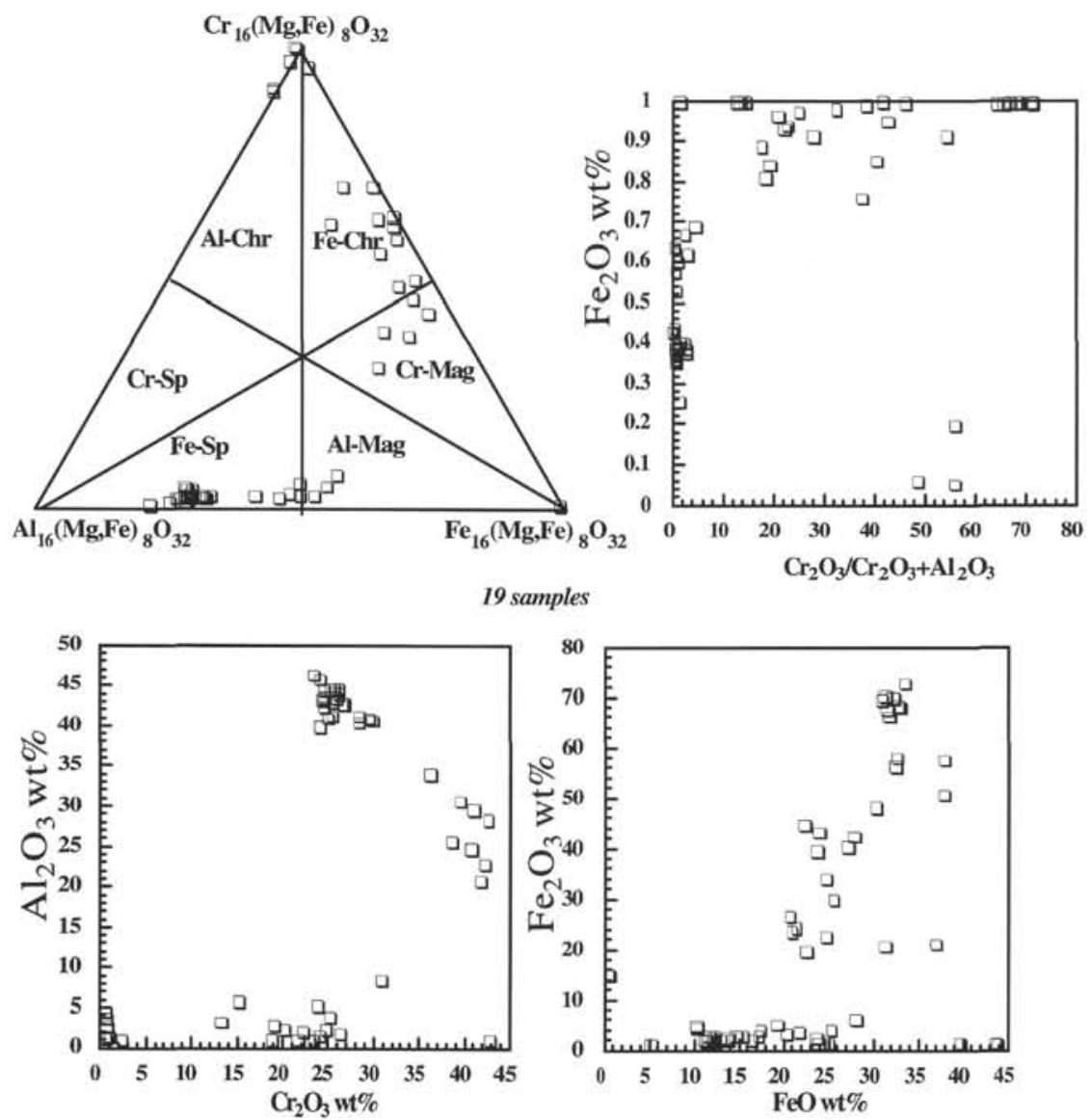

Figure 3. Mineral chemistry of chromites and alteration products plotted on the ternary diagram for $\mathrm{Al}_{16}(\mathrm{Mg}, \mathrm{Fe})_{8} \mathrm{O}_{32}, \mathrm{Cr}_{16}\left(\mathrm{Mg}_{2} \mathrm{Fe}\right)_{8} \mathrm{O}_{32}$, and $\mathrm{Fe}{ }_{16}\left(\mathrm{Mg}_{2} \mathrm{Fe}\right)_{8} \mathrm{O}_{32}$, and binary correlations among $\mathrm{Cr}_{2} \mathrm{O}_{3}, \mathrm{Al}_{2} \mathrm{O}_{3}, \mathrm{Fe}_{2} \mathrm{O}_{3}$, and $\mathrm{FeO}$. Chromites $(\mathrm{Chr})$ and minor $\mathrm{Fe}$ spinels ( $\mathrm{Fe}$-Sp) occur as primary phases interstitial to $\mathrm{Fe}$ spinel and $\mathrm{Al}$ magnetite (Al-Mag) fields represent secondary phases, both replacing primary phases and in veins. $\mathrm{Fe}$ chromite and $\mathrm{Cr}$ magnetite compositions were measured in altered grains. Only some analyses of Fe chromites represent the rims of unaltered chromite. 


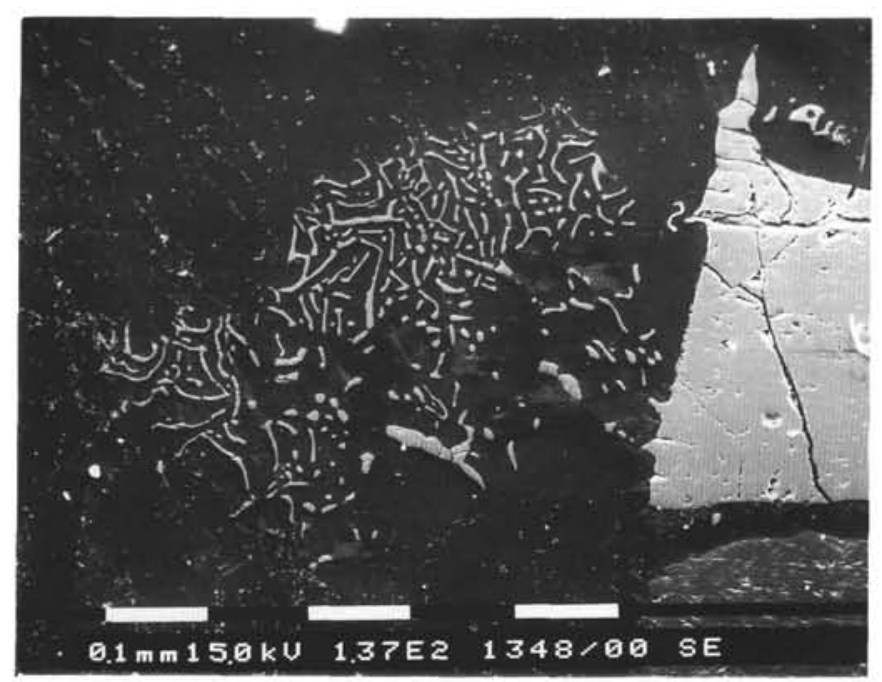

Figure 4. Secondary electron photomicrograph. Bar scale in photograph is $0.1 \mathrm{~mm}$. Myrmekitic intergrowth of ilmenite and $\mathrm{Ti}$ magnetite (light gray), and orthopyroxene (dark gray), in Sample 153-920D-18R-3, 50-54 cm.

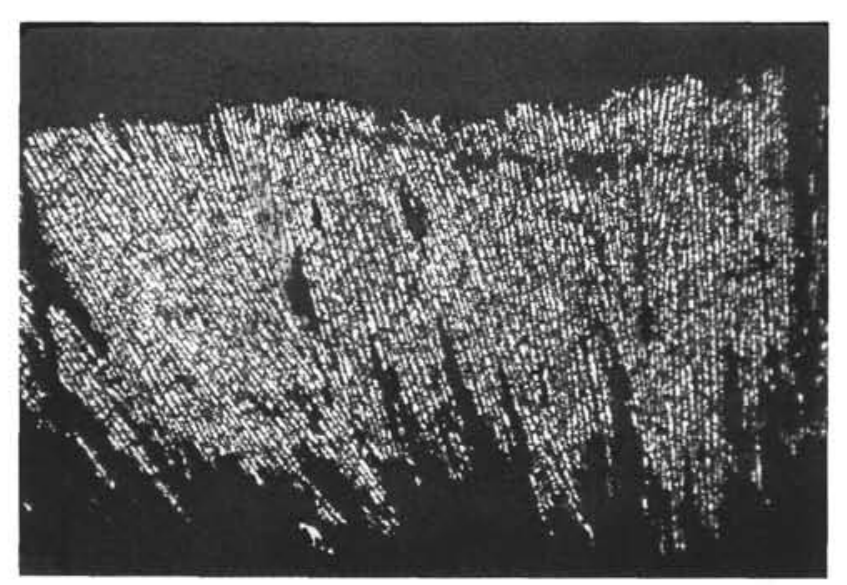

Figure 5. Thin-section photomicrograph of Sample 153-920D-8R-1, 6-10 $\mathrm{cm}, 250 \times$. Vein-filling (top) intergrowth of pyrrhotite (light gray) and chlorite (dark gray) diffusing in the bounding rock (bottom).
Table 3. Mineral compositions of garnets from Holes 920B and 920D.

\begin{tabular}{|c|c|c|c|c|}
\hline Hole: & $920 \mathrm{~B}$ & $920 \mathrm{~B}$ & $920 \mathrm{D}$ & $920 \mathrm{D}$ \\
\hline Core, section: & $10 \mathrm{R}-3$ & $10 \mathrm{R}-3$ & $6 \mathrm{R}-2$ & $6 \mathrm{R}-2$ \\
\hline Interval $(\mathrm{cm})$ : & $0-5$ & $0-5$ & $27-30$ & $27-30$ \\
\hline Analysis no.: & 1 & 2 & 1 & 2 \\
\hline Mineral: & Hydrogarnet & Hydrogarnet & Garnet & Hydrogarnet \\
\hline \multicolumn{5}{|l|}{ Oxides } \\
\hline $\mathrm{SiO}_{2}$ & 38.45 & 38.62 & 36.19 & 35.15 \\
\hline $\mathrm{TiO}_{2}^{2}$ & 0.02 & 0.00 & 0.00 & 0.00 \\
\hline $\mathrm{Cr}_{2} \mathrm{O}_{3}$ & 0.32 & 0.33 & 0.21 & 0.25 \\
\hline $\mathrm{Al}_{2} \mathrm{O}_{3}$ & 22.24 & 22.31 & 0.85 & 0.06 \\
\hline $\mathrm{Fe}_{2} \mathrm{O}_{3}$ & 0.24 & 0.46 & 30.48 & 31.03 \\
\hline $\mathrm{FeO}$ & 0.00 & 0.00 & 0.00 & 0.00 \\
\hline $\mathrm{MnO}$ & 0.09 & 0.07 & 0.14 & 0.12 \\
\hline $\mathrm{CaO}$ & 36.47 & 36.68 & 34.36 & 33.51 \\
\hline $\mathrm{Na}_{2} \mathrm{O}$ & 0.00 & 0.00 & 0.00 & 0.00 \\
\hline $\mathrm{K}_{2} \mathrm{O}$ & 0.18 & 0.18 & 0.14 & 0.10 \\
\hline Total & 98.01 & 98.65 & 102.37 & 100.22 \\
\hline \multicolumn{5}{|l|}{ Cations } \\
\hline $\mathrm{Si}$ & 2.944 & 2.940 & 2.972 & 2.963 \\
\hline $\mathrm{Ti}$ & 0.001 & 0.000 & 0.000 & 0.000 \\
\hline $\mathrm{Cr}$ & 0.019 & 0.020 & 0.014 & 0.017 \\
\hline $\mathrm{Al}$ & 2.007 & 2.001 & 0.082 & 0.006 \\
\hline $\mathrm{Fe}^{3+}$ & 0.014 & 0.026 & 1.884 & 1.968 \\
\hline $\mathrm{Fe}^{2+}$ & 0.000 & 0.000 & 0.000 & 0.000 \\
\hline $\mathrm{Mn}$ & 0.006 & 0.005 & 0.010 & 0.009 \\
\hline $\mathrm{Ca}$ & 2.992 & 2.991 & 3.024 & 3.027 \\
\hline $\mathrm{Na}$ & 0.000 & 0.000 & 0.000 & 0.000 \\
\hline K & 0.018 & 0.018 & 0.015 & 0.011 \\
\hline \multicolumn{5}{|l|}{ End members } \\
\hline Grossular & 0.980 & 0.975 & 0.058 & 0.016 \\
\hline Almandine & 0.000 & 0.000 & 0,000 & 0.000 \\
\hline Pyrope & 0.000 & 0.000 & 0.000 & 0.000 \\
\hline Spessartine & 0.002 & 0.002 & 0.003 & 0.003 \\
\hline Andradite & 0.007 & 0.013 & 0.932 & 0.973 \\
\hline Uvarovite & 0.010 & 0.010 & 0.007 & 0.008 \\
\hline Ti-Al garnet & 0.000 & 0.000 & 0.000 & 0.000 \\
\hline $\mathrm{Na}-\mathrm{Ti}$ garnet & 0.001 & 0.000 & 0.000 & 0.000 \\
\hline
\end{tabular}

Notes: Values are in weight percent. Cations were calculated assuming stoichiometry and charge balance. 
Table 4. Mineral chemistry of ilvaite, Sample 153-920D-18R-3, 50-54 cm.

\begin{tabular}{lrrr}
\hline Analysis no.: & \multicolumn{1}{c}{1} & \multicolumn{1}{c}{2} & \multicolumn{1}{c}{3} \\
\hline Oxide & & & \\
$\mathrm{SiO}_{2}$ & 31.35 & 31.37 & 31.65 \\
$\mathrm{Cr}_{2} \mathrm{O}_{3}$ & 0.18 & 0.09 & 0.00 \\
$\mathrm{Al}_{2} \mathrm{O}_{3}$ & 0.03 & 0.00 & 0.32 \\
$\mathrm{FeO}$ & 50.27 & 50.46 & 50.10 \\
$\mathrm{MnO}$ & 0.54 & 0.50 & 0.19 \\
$\mathrm{MgO}$ & 1.18 & 1.30 & 1.30 \\
$\mathrm{CaO}$ & 14.04 & 14.02 & 14.01 \\
$\mathrm{~K}_{2} \mathrm{O}$ & 0.07 & 0.00 & 0.00 \\
$\mathrm{H}_{2} \mathrm{O}$ & 2.27 & 2.27 & 2.27 \\
$\mathrm{Total}$ & 99.93 & 100.01 & 99.84 \\
$\mathrm{Cations} /$ anions & & & \\
$\mathrm{Si}$ & 2.069 & 2.068 & 2.086 \\
$\mathrm{Cr}$ & 0.009 & 0.005 & 0.000 \\
$\mathrm{Al}$ & 0.002 & 0.000 & 0.025 \\
$\mathrm{Fe}$ & 2.774 & 2.782 & 2.762 \\
$\mathrm{Mn}$ & 0.030 & 0.028 & 0.011 \\
$\mathrm{Mg}$ & 0.116 & 0.128 & 0.128 \\
$\mathrm{Ca}$ & 0.993 & 0.990 & 0.989 \\
$\mathrm{~K}$ & 0.006 & 0.000 & 0.000 \\
$\mathrm{OH}$ & 1.000 & 1.000 & 1.000 \\
\hline
\end{tabular}

Notes: Values are in weight percent. Cations calculated on the basis of 8.5 oxygens.

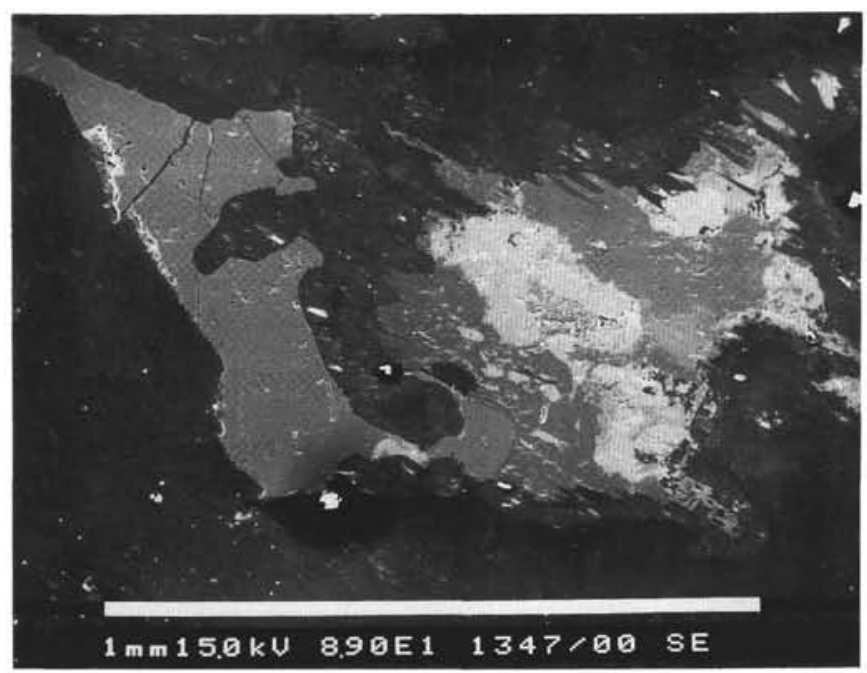

Figure 6. Secondary electron photomicrograph in Sample 153-920D-18R-3, $50-54 \mathrm{~cm}$. Bar scale in photograph is $1 \mathrm{~mm}$. Left to right: the large gray grain showing a lobate contact with silicate is ilvaite. The dark silicate in contact with ilvaite is orthopyroxene. The lamellar phase in contact with orthopyroxene is magnetite, the white phases, partially intergrown with magnetite, are sulfides. 